\title{
Molecular Epidemiology of Babesia and Theileria Species in Sheep in Kars Region of Turkey
}

\author{
Kars Yöresindeki Koyunlarda Babesia ve Theileria Türlerinin Moleküler \\ Epidemiyolojisi \\ (D) Nilgün Aydın ${ }^{1}$, (1) Zati Vatansever ${ }^{1}$, (1) Mükremin Özkan Arslan² \\ ${ }^{1}$ Kafkas University Faculty of Veterinary Medicine, Department of Parasitology, Kars, Turkey \\ ${ }^{2}$ Kafkas University Faculty of Medicine, Department of Medical Parasitology, Kars, Turkey
}

Cite this article as: Aydın N, Vatansever Z, Arslan MÖ. Molecular Epidemiology of Babesia and Theileria Species in Sheep in Kars Region of Turkey. Turkiye Parazitol Derg 2022;46(1):20-27.

\begin{abstract}
Objective: This study aimed to evaluate Babesia and Theileria species and vector ticks in sheep in the Eastern Anatolia Region of Turkey.

Methods: Blood samples were collected from 960 sheep, and ticks were collected from the same animals between January and December 2017. The reverse line blotting (RLB) method was used to analyze Babesia and Theileria piroplasm DNAs. Ticks and tick egg clusters were evaluated in terms of Babesia and Theileria species using the RLB technique.

Results: Microscopically, 3.96\% (38/960) of Theileria spp. piroplasm forms were identified; however, no Babesia spp. piroplasm forms were identified. The distribution of Babesia and Theileria spp. by RLB was 35.52\% (341/960). The species identified included Theileria ovis $(24.79 \%, 238 / 960)$, Theileria sp. (6.15\%, 59/960), Theileria sp. OT3 (4.27\%, 41/960), and Babesia ovis $(0.31 \%, 3 / 960)$. Tick infestation was found in $17.5 \%$ (168/960) of the sheep. Dermacentor marginatus (66.31\%), Haemaphysalis parva (32.73\%), Hae. punctata (0.21\%), Rhipicephalus bursa (0.53\%), and Hyalomma marginatum (0.11\%) were identified in the infected sheep. No pathogenic species were found in the analysis of egg clusters or tick carcasses according to the RLB method.

Conclusion: Theileria ovis is the theileriosis agent in sheep in the study region. Species commonly detected in tick-infested sheep were D. marginatus and Hae. parva.
\end{abstract}

Keywords: Babesia, Theileria, reverse line blotting, sheep, Turkey

öz

Amaç: Çalışmamızda, Kars yöresinde yetiştirilen koyunlarda Babesia ve Theileria türleri ile vektör kenelerin belirlenmesi amaçlanmiştır.

Yöntemler: Ocak-Aralık 2017 tarihleri arasında 960 koyundan kan örnekleri alınmış ve aynı hayvanların üzerinden kene toplanmıştır. Babesia ve Theileria piroplasm DNA'ları reverse line blotting (RLB) yöntemi ile incelenmiştir. Keneler ve kene yumurta kümeleri de Babesia ve Theileria türleri yönünden RLB tekniği ile değerlendirilmiştir.

Bulgular: Mikroskobik olarak \%3,96 (38/960) oranında Theileria spp. piroplasm formları tespit edilmiş olup, Babesia spp. piroplasm formları saptanmamıştır. RLB ile Babesia ve Theileria türlerinin yaygınlığ1 \%35,52 (341/960) olarak tespit edilmiş olup, başlica Theileria ovis \%24,79 (238/960), Theileria spp., \%6,15 (59/960), Theileria sp. OT3 \%4,27 (41/960) ve Babesia ovis \%0,31 (3/960) türleri/genotipleri belirlenmiştir. Araştırmada kene enfestasyonlarının prevalansı \%17,5 (168/960) olarak saptanmıştır. Enfeste koyunlarda Dermacentor marginatus \%66,31, Haemaphysalis parva \%32,73, Haemaphysalis punctata \%0,21, Rhipicephalus bursa \%0,53 ve Hyalomma marginatum \%0,11 türleri identifiye edilmiştir. RLB yöntemi ile yumurta kümeleri veya kene karkaslarının analizinde patojenik türe rastlanmamışır.

Sonuç: Bölgede koyunlarda theileriosis etkeni olarak Theileria ovis'in sorumlu tür olduğu tespit edilmiştir. Kene ile enfeste koyunlarda yaygın olarak belirlenen türler ise D. marginatus ve Hae. parva'dır.

Anahtar Kelimeler: Babesia, Theileria, reverse line blotting, koyun, Türkiye 


\section{INTRODUCTION}

Tick-borne diseases caused by Babesia and Theileria are responsible for deaths and economic losses in sheep breeding (1).

Reverse line blotting (RLB) has been preferred as a diagnostic method due to the determination of multiple infectious agents simultaneously and used frequently in the diagnosis of parasitic diseases especially babesiosis and theileriosis. Hence, this method has been used successfully for the diagnosis of Babesia and Theileria species in parasitological researches $(2,3)$.

There have been various studies on Babesia and Theileria infections and vectors in sheep in many countries and also different regions of Turkey (4-8). Babesia ovis, B. crassa, B. motasi, T. ovis, T. uilenbergi, T. luwenshuni, T. separata, Theileria sp. MK, Theileria sp. OT1 and Theileria sp. OT3 has been reported in sheep and goats of Turkey (1). However, there is no comprehensive research on Babesia and Theileria species and vector ticks that carry these blood parasites in sheep in the Kars province. Kars, located in the North-Eastern Anatolia Region of Turkey, is an area where pastured livestock breeding is carried out as well as intensive livestock breeding.

This study is aimed to determine Babesia and Theileria species in sheep by molecular methods, identify vector ticks, determine Babesia and Theileria species in ticks, and determine their molecular epidemiology in Kars.

\section{METHODS}

Ethics Committee Approval: For this study, Kafkas University Animal Experiments from the Local Ethics Committee (letter dated: 15.12.2016 and numbered: 2016-131) approval has been received.

\section{Study Area}

The study took place in the province of Kars located in the NorthEast Anatolia Region of Turkey and the Georgia-Armenia border (40³6'04.82”N, 4305'50.83”E). Eight research foci (Akyaka, Arpacay, Digor, Kagızman, Kars City Center, Sarıkamıs, Selim, and Susuz) were visited every month (between January 2017 and December 2017). Ten blood samples and ticks were collected from each randomly selected farm (monthly 80, 960 in total, sheep breed 470 Akkaraman and 490 Morkaraman, age 210 of one-year-old, 244 of two years old and 506 of $\geq$ three-years-old). Blood smears were prepared for each collected blood sample. The sheep were also examined clinically in terms of theileriosis and babesiosis and as to whether they had any such infections previously. The foci/settlement with 96 different herds/sheepfold where the study was conducted are shown in Figure 1.

\section{DNA Extraction from Blood Samples and Tick Identification and Egg Cluster Collection}

Blood samples were collected from the Vena jugularis of sheep. DNA extraction from blood samples was performed using a commercial DNA isolation kit (Quick-DNATM Miniprep Kit, Zymo Research, USA) following the manufacturer's protocol. Genomic DNA concentration $(\mathrm{ng} / \mathrm{mL})$ was measured using a NanoDrop spectrophotometer (Biotek ${ }^{\circledR}$ Instruments, Inc. USA). The obtained genomic DNAs were stored at $-20{ }^{\circ} \mathrm{C}$ until polymerase chain reaction (PCR) analysis.

Sheep were examined in terms of tick infestation, and nymphs or adult ticks from infected animals were collected. Engorged female ixodid ticks were ovulated at $28{ }^{\circ} \mathrm{C}$ and $85 \%$ relative humidity, and the nymphs were allowed to molt in the laboratory. Identification of ticks at the species level was performed under a stereomicroscope (9). Tick and egg clusters were stored at -20 ${ }^{\circ} \mathrm{C}$ until DNA extraction. DNA isolation was performed from engorged nymph-female-adult ticks and egg clusters using a commercial kit (Quick-DNATM Tissue/Insect Miniprep Kit, Zymo Research, USA).

\section{PCR and Monitoring of Products}

PCR of DNA samples used in the study was carried out using RLB-F2 and RLB-R2 primers that amplify the variable V4 region of the 18S SSU rRNA gene of Babesia and Theileria species. Accordingly, 111 PCR products were visualized by ultraviolet (UV) transillumination in a $1.5 \%$ agarose gel after electrophoresis and evaluated for the presence of specific bands. The remaining part of the PCR products (849) was stored at $4{ }^{\circ} \mathrm{C}$ for use in RLB testing.

A $25 \mu \mathrm{L}$ solution $\left(\mathrm{dH}_{2} \mathrm{O} 11.5 \mu \mathrm{L}, 5 \mathrm{x}\right.$ PCR Buffer $5 \mu \mathrm{L}, 25 \mathrm{mM}$ $\mathrm{MgCl}_{2} 1.5 \mu \mathrm{L}, 10 \mathrm{mM}$ dNTPs $1.5 \mu \mathrm{L}, 5 \mathrm{U} / \mathrm{uL}$ Taq $0.5 \mu \mathrm{L}$, reverse and forward primers $(20 \mathrm{pmol} / \mu \mathrm{L}) 1.25 \mu \mathrm{L}$, and $2.5 \mu \mathrm{L}$ template DNA) was used for a touchdown PCR using a thermal cycler (Biometra, Analytik Jena, USA). Positive and negative control DNA samples were used for each reaction. Touchdown PCR cycling parameters were applied according to Ozubek (8). Five microliters of PCR products were visualized by UV transillumination in a $1.5 \%$ agarose gel after electrophoresis and staining with ethidium bromide. Biotin-labeled PCR products $(20 \mu \mathrm{L})$ were kept at $4{ }^{\circ} \mathrm{C}$ for RLB.

\section{RLB}

To detect Babesia and Theileria species, a RLB hybridization was performed on the PCR products, as described previously (10). Briefly, to $20 \mu \mathrm{L}$ of the PCR products, $2 \mathrm{X}$ SSPE/0.1\% SDS was added to a final volume of $150 \mu \mathrm{L}$ and held in the Thermal Cycler at $99{ }^{\circ} \mathrm{C}$ for $10 \mathrm{~min}$ and denatured for RLB hybridization. A total of 16 different probes which are Catchall (Babesia + Theileria) and lineage-specific Babesia spp., and Theileria spp., probes, as well as some specific genotypes and probes which were identified for Babesia and Theileria species in sheep, were connected to a membrane (4,11-13). Primer and Probes were provided by the Humanizing Genomics Macrogen (Macrogen, Korea).

RLB probes and their nucleotide sequences and concentrations are provided in Table 1 (4,10-14).

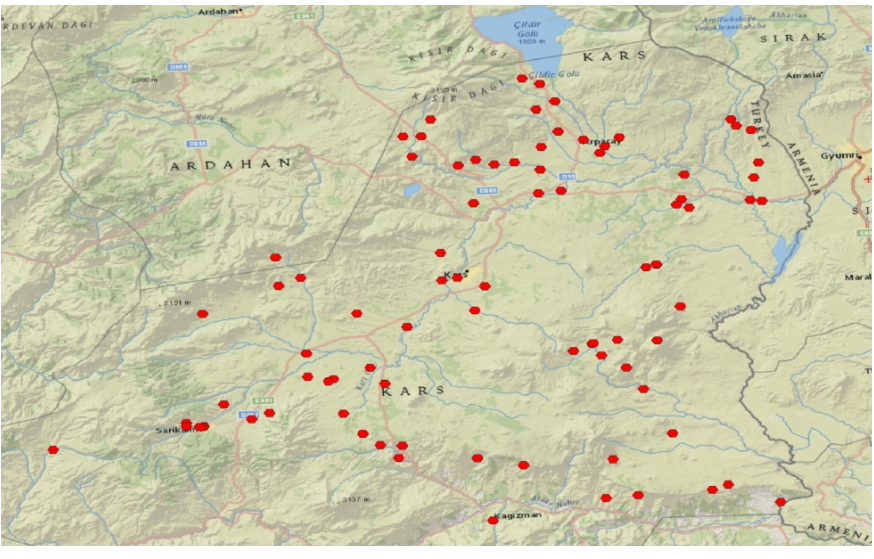

Figure 1. Foci/settlement where the study was conducted 
The Biotin- $\mathrm{C}$ membrane was constructed as described previously (modifying the concentration and residence times and steps of some solutions) $(10,11)$.

\section{Sequence Analysis}

In order to confirm the results obtained by PCR and RLB, a total of 4 isolates consist of Babesia ovis, Theileria ovis, and Theileria sp. and Theileria sp. OT3 genotypes were chosen for sequencing. DNA sequences obtained were evaluated with FinchTV chromatogram viewer is a popular desktop application that was developed by Geospiza, Inc., and compared for similarity to sequences deposited in GenBank. Isolates belonging to Babesia and Theileria species and genotypes were amplified with Nbab1F/Nbab1R primers targeting the $18 S$ rRNA gene region and then amplicons obtained with PCR were purified and bidirectionally sequenced with Nbab1F and Nbab1R (Macrogen, Turkey) (15). Sequence analyzes of tree species and one genotype determined in sheep were submitted to the Genbank database and an accession number was obtained.

\section{Statistical Analysis}

The results obtained from microscopic examination and RLB were compared by Mann-Whitney U tests for pairwise comparisons, and Kruskal-Wallis tests for multiple repetitive measurements (according to study site, month, season, breed, and age) using the SPSS 20.0 program. The incidence of Babesia and Theileria species was evaluated. Values of $\mathrm{p}<0.05$ were considered to be statistically significant (16).

\section{RESULTS}

In the microscopic examination of the peripheral blood smears, Theileria spp. piroplasm forms were detected in all foci in 38 (3.96\%) samples; however, Babesia spp. piroplasm forms were not found. Distribution of microscopic examination results by months, Theileria spp. in one of the two months with the highest positivity for piroplasm forms, $10 \%(8 / 80)$ of the sheep were found positive in March and 17.5\% (14/80) of the sheep were positive in May $(\mathrm{p}<0.05)$. Considering the distribution by age groups, Theileria spp. microscopically, it was detected at a rate of $4.76 \%(10 / 210)$ in sheep up to one year old, and at least $1.64 \%$ (4/244) in two-year-olds ( $\mathrm{p}>0.05)$.

The RLB image of Babesia and Theileria species/genotypes is shown in Figure 2. As seen in the figure, PCR products of Babesia and Theileria species were hybridized on the membrane to which species and specific probes were attached, and gave signals with their strain-specific probes.

Sixty-seven (60.4\%) of 111 samples that were run out on agarose gel, were found positive for species of Babesia and Theileria. Also, 7 out of 51 samples that were negative on gel electrophoresis, were found positive with RLB. In total 60 samples were found positive that agarose gel electrophoresis and RLB.

It was determined that Babesia and Theileria species were prevalent in $35.52 \%$ (341/960) of the sheep. Single-species infections occurred at a rate of $93.55 \%$ (319/341) and mixed infections at $3.23 \%(11 / 341)$ (Table 2).

According to the distribution of RLB results by foci/settlement, (Table 3) the highest distribution of Babesia and Theileria spp. were determined in Kagizman (49.17\%, 59/120) and the lowest in Arpacay (20.83\%, 25/120). Babesia ovis was found at a very low level with only three positive samples (two of the positive animals were found in Akyaka and the other in Kag1zman).

The distribution of RLB results by months is presented in Table 4. It was determined that the Babesia and Theileria spp. were seen mostly in May $(72.5 \%, 58 / 80)$ and least in September $(10.00 \%, 8 / 80)$. Comparing the distribution of RLB results by months, the difference was not statistically significant for Babesia ovis ( $p>0.05$ ); however, it was significant for Theileria species and genotypes $(\mathrm{p}<0.05)$. Theileria ovis was seen every month of the year.
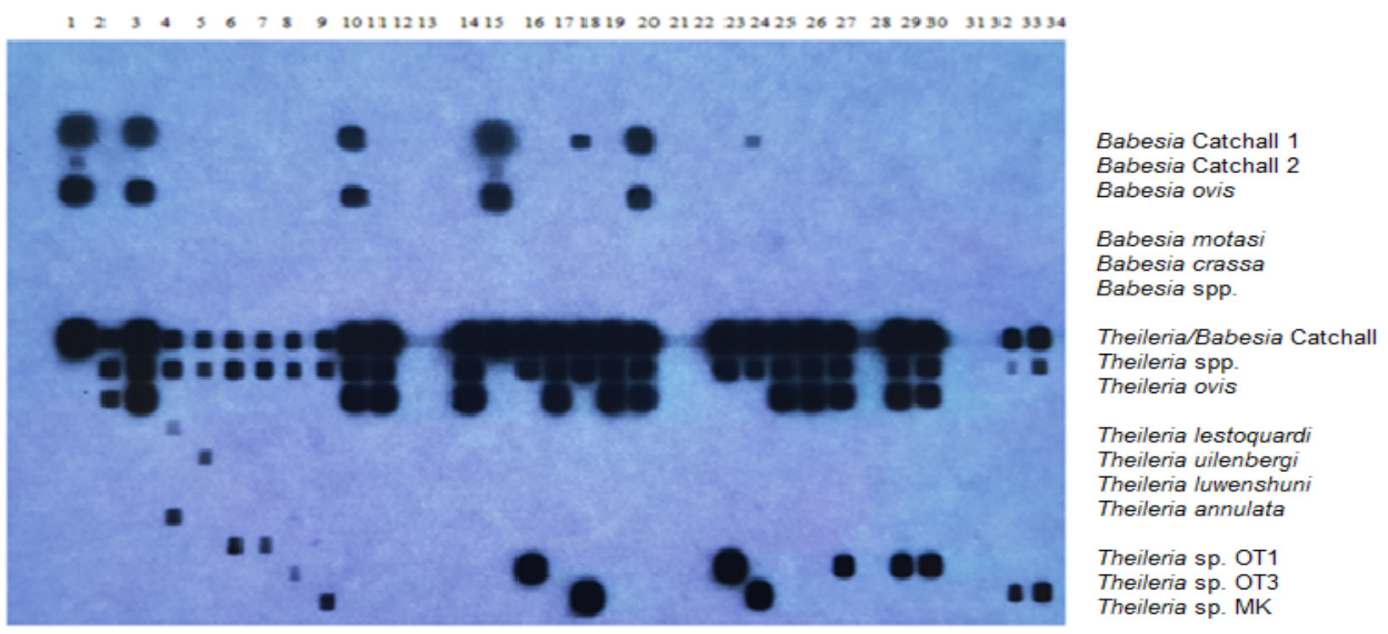

Figure 2. RLB image of Babesia and Theileria species/genotypes.

Probe rows from left to right, positive control from top to bottom, and samples 1-9 positive controls (1. B. ovis, 2. T. ovis, 3. B. ovis+T. ovis, 4. T. lestoquardi/T. annulata, 5. T. uilenbergi, 6. T. luwenshuni, 7. Theileria sp. OT1, 8. Theileria sp. OT3, 9. Theileria sp. MK, 10. positive control), 11,14-20,23-27,29,30,33,34 Field Samples $(11,14,17,19,25,26$ T. ovis, 15. B. ovis, 16,23. Theileria sp. OT3, 18,24,33,34. Theileria sp. 20. B. ovis+T. ovis, 27,29,30. T. ovis+ Theileria sp. OT3) 12,13,21,22,28, Buffer, 31,32. Negative control (Uninfected sheep blood DNA)

RLB: Reverse line blotting 
Tick infestation was found at a rate of $17.5 \%$ (168/960) in sheep. In infected sheep, infestations with a single species were found at a rate of $13.75 \%$ (132/960), while infestations with more than one tick species (mixed) were detected at 3.75\% (36/960). At least one, and at most sixty-six ticks were collected from tick-infested sheep. The distribution of tick infestation in sheep by months is detailed in Table 5.

A total of 944 ticks, one nymph, and larvae, were collected from the infested sheep. The prevalence of tick species detected in sheep in the study was determined as Dermacentor marginatus $66.31 \%$ (626/944), Haemaphysalis parva 32.73\% (309/944), Haemaphysalis punctata $0.21 \%$ (2/944), Rhipicephalus bursa $0.53 \%$ (5/944), Hyalomma marginatum $0.11 \%$ (1/944), and Haemaphysalis sp. larvae $0.11 \%$ (1/944). The engorged nymph was made molt and identified as $R$. bursa. It was determined that the dominant genera have belonged to Dermacentor (66.31\%) and Haemaphysalis (33.05\%). Dermacentor marginatus was mostly seen in Kars City Center at a rate of $25.63 \%$ (242/944), while this species was never found in Kagızman. Haemaphysalis parva was mostly seen in Digor at a rate of $15.36 \%$ (145/944), and it was not detected in Kars City Center. Haemaphysalis punctata was found only in Sarıkamıs $(0.21 \%, 2 / 944)$. Rhipicephalus bursa was found mostly in Kagizman $(0.42 \%, 4 / 944)$ and least in Digor $(0.11 \%$, 1/944). Hyalomma marginatum was detected only in Akyaka $(0.11 \%, 1 / 944)$. One Haemaphysalis sp. larva was found in Selim. When the distribution of tick species in sheep in the Kars Region was compared according to foci/settlement, the difference was statistically between $D$. marginatus and Hae. parva was significant for $(\mathrm{p}<0.05)$.

DNA extraction from adult ticks collected from sheep was carried out by creating tick pools of 1 to 20 according to the species. The collected engorged female ticks were left to lay eggs and a total of 65 egg clusters (56 D. marginatus and, 9 Hae parva) were obtained. No pathogenic species were found in the egg clusters.

The 1600 bp region of the 18S rRNA gene of Babesia (B. ovis) and Theileria (T. ovis, Theileria sp., and Theileria sp. OT3) species or genotypes detected in the analysis of blood samples with RLB were sequenced and compared to other Theileria and Babesia sequences available in GenBank. Theileria ovis, Theileria sp. OT3 and B. ovis were found $100 \%$ identical with the sequences. Because Theileria sp. was found similar to T. orientalis (T. orientalis/T. buffeli/T. sergenti) at $99.05 \%$ and $T$. sinensis at $98.92 \%$, it was judged as Theileria sp. Isolates obtained in the study were registered to the GenBank database with MN493109 (Theileria sp. OT3),

Table 1. Nucleotide sequences and concentrations for probes used in RLB

\begin{tabular}{|c|c|c|c|}
\hline Probes & Sequence (5'-3') & pmol/150 $\mu \mathrm{L}$ & Reference \\
\hline Theileria/Babesia catchall & AmMC6-TAATGGTTAATAGGA(AG)C(AG)GTTG & 200 & 11 \\
\hline Theileria spp. & AmMC6-TGATGGGAATTTAAACC(CT)CTTCCA & 200 & 4 \\
\hline T. ovis & AmMC6-TTTTGCTCCTTTACGAGTCTTTGC & 400 & 4 \\
\hline T. lestoquardi & AmMC6-ATTGCTTGTGTCCCTCCG & 400 & 12 \\
\hline T. uilenbergi & AmMC6-TGCATTTTCCGAGTGTTACT & 400 & 12 \\
\hline T. luwenshuni & AmMC6-TCGGATGATACTTGTATTATC & 400 & 12 \\
\hline T. annulata & AmMC6-CCTCTGGGGTCTGTGCA & 400 & 10 \\
\hline Theileria sp. OT1 & AmMC6-ATCTTCTTTTTGATGAGTTGGTGT & 400 & 4 \\
\hline Theileria sp. ОТ3 & AmMC6-ATTTTсTCTTTTTATATGAGTTTT & 400 & 4 \\
\hline Theileria sp. MK & AmMC6-CATTGTTTCTTCTCATGTC & 400 & 13 \\
\hline Babesia catchall 1 & AmMC6-ATTAGAGTGTTTCAAGCAGAC & 200 & 14 \\
\hline Babesia catchall 2 & AmMC6-ACTAGAGTGTTTCAAACAGGC & 200 & 14 \\
\hline Babesia spp. & AmMC6-CCT(GT)GGTAATGGTTAATAGGAA & 400 & 12 \\
\hline B. ovis & AmMC6-GCGCGCGGCCTTTGCGTTTACT & 400 & 4 \\
\hline B. motasi & AmMC6-ATTGGAGTATTGCGCTTGCTTTTT & 400 & 4 \\
\hline B. crassa & AmMC6-TTATGGCCCGTTGGCTTAT & 400 & 12 \\
\hline
\end{tabular}

Table 2. Distribution of Babesia and Theileria infections according to RLB results ( $\mathrm{n}=960)$

\section{RLB}

Babesia and Theileria species

\begin{tabular}{|c|c|c|c|c|c|c|c|c|c|}
\hline \multicolumn{4}{|c|}{$\begin{array}{l}\text { Total } \\
\text { Infection rate (\%) }\end{array}$} & \multicolumn{4}{|c|}{$\begin{array}{l}\text { Single-species } \\
\text { Infection rate (\%) }\end{array}$} & \multicolumn{2}{|c|}{$\begin{array}{l}\text { Mixed } \\
\text { Infection rate (\%) }\end{array}$} \\
\hline B. ovis & T. ovis & Theileria sp. & $\begin{array}{l}\text { Theileria } \\
\text { sp. OT3 }\end{array}$ & B. ovis & T. ovis & $\begin{array}{l}\text { Theileria } \\
\text { sp. }\end{array}$ & $\begin{array}{l}\text { Theileria } \\
\text { sp. OT3 }\end{array}$ & $\begin{array}{l}\text { B. ovis } \\
+ \\
\text { T. ovis }\end{array}$ & $\begin{array}{l}\text { T. ovis } \\
+ \\
\text { Theileria sp. OT3 }\end{array}$ \\
\hline \begin{tabular}{|l|}
3 \\
$(0.31)$
\end{tabular} & $\begin{array}{l}238 \\
(24.79)\end{array}$ & $\begin{array}{l}59 \\
(6.15)\end{array}$ & $\begin{array}{l}41 \\
(4.27)\end{array}$ & $\begin{array}{l}1 \\
(0.10)\end{array}$ & $\begin{array}{l}227 \\
(23.65)\end{array}$ & $\begin{array}{l}59 \\
(6.15)\end{array}$ & $\begin{array}{l}32 \\
(3.33)\end{array}$ & $\begin{array}{l}2 \\
(0.21)\end{array}$ & $\begin{array}{l}9 \\
(0.94)\end{array}$ \\
\hline
\end{tabular}

RLB: Reverse line blotting 


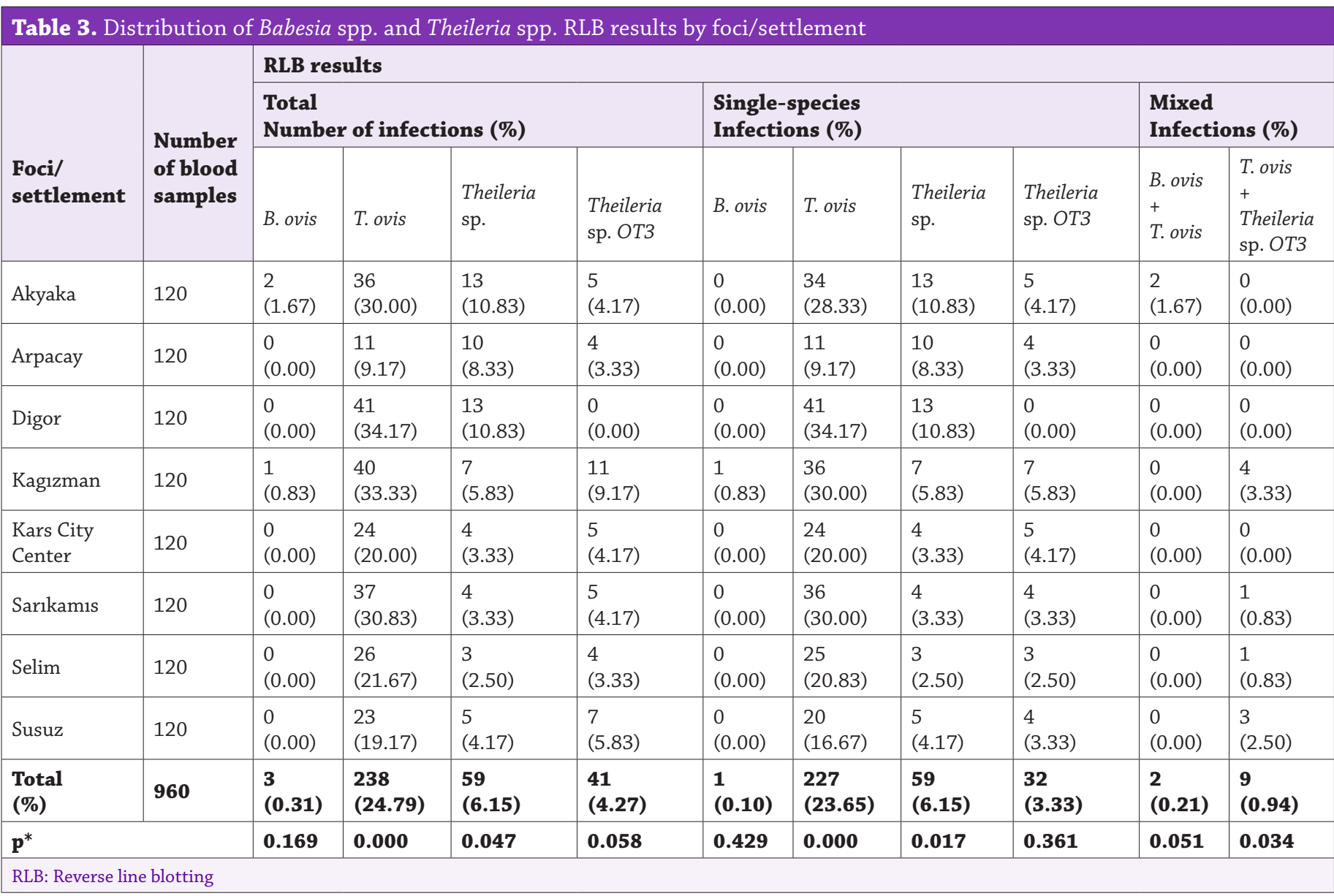

MN493110 (Theileria sp.), MN493111 (T. ovis), and MN493112 (B. ovis) accession numbers.

\section{DISCUSSION}

In this study carried out on sheep in the Kars Region, Theileria spp. piroplasm forms were detected in 38 (3.96\%) of 960 sheep by microscopic examination, but Babesia spp. were not found, and the rate determined in this study was found to be similar with some studies $(2,5,8)$.

In a study on sheep and goats in the Elazig Region, Theileria spp. piroplasm forms were identified by microscopic examination in $15.78 \%$ of animals younger than one year old and $31.81 \%$ of animals older than one (17). In this study, the results are not similar to other previous studies in that Theileria spp. were found to be higher in animals up to the age of one (4.76\%) compared to other groups (1.64-4.74\%) ( $p>0.05$ ). This is due to the unequal distribution between age groups when sampling.

In recent years, there have been many studies using molecular methods on babesiosis and theileriosis in sheep in various countries of the world and in Turkey $(5,6,18,19)$. In the present study, according to the RLB method, B. ovis, T. ovis, Theileria sp., Theileria sp., OT3, a total of three species and one genotype were identified. When the studies on the prevalence of Babesia and Theileria species in sheep were examined, it was determined that the infection rate differed in different regions of Turkey with the results obtained from this study. The prevalence of Babesia ovis (0.31\%) was determined at a very low rate since the sampled animals did not show clinical signs and were randomly selected animals. However, it has been reported that blood parasites are common in every region of Turkey. Both in this study and in other studies, Theileria species were found to be more common than Babesia species $(6,8)$. The higher rate of the detected species in Kagizman and Digor can be explained by the fact that the province of Kars where the study was conducted has geographic differences within itself as these settlements are lower in altitude and there are also valley settlements.

To date, no research has been found that examines the distribution of Babesia and Theileria species according to months and seasons. As seen in previous studies on tick-borne diseases, it is seen in the months and seasons when ticks are active (9).

It has been reported that Babesia and Theileria species can be found in hosts other than their natural hosts (7). In Turkey and various locations of the world, T. orientalis (T. orientalis/T. buffeli/T. sergenti) and T. sinensis groups of species, which have benign effects, have been reported $(20,21)$ in cattle. Additional studies of this species in other regions of Turkey and different gene regions (such as ITS 1, 2, and 5.8S, Cytochrome b, heat shock protein 70) are needed to clarify this subject.

There are numerous studies revealing tick species in Turkey, in which the data for Eastern Anatolia Region are presented (2224). Also, a total of 17 tick species including 16 from the Ixodidae family and one from the Argasidae family $(25,26)$ have been described in sheep and goats. In Kars, D. marginatus was found at a high rate of $66.31 \%$ in sheep, followed by Hae. parva at a rate of $32.73 \%$. According to these results, compared to other studies, D. marginatus and Hae. parva species showed a higher prevalence in the Kars province. Dermacentor marginatus is a tick 
Table 4. Distribution of RLB results of Babesia spp. and Theileria spp. species by months

\begin{tabular}{|c|c|c|c|c|c|c|c|c|c|c|c|}
\hline \multirow[b]{3}{*}{ Month } & \multirow[b]{3}{*}{$\begin{array}{l}\text { Number } \\
\text { of blood } \\
\text { samples }\end{array}$} & \multicolumn{10}{|c|}{ RLB results } \\
\hline & & \multicolumn{4}{|c|}{$\begin{array}{l}\text { Total } \\
\text { Number of infections (\%) }\end{array}$} & \multicolumn{4}{|c|}{$\begin{array}{l}\text { Single-species } \\
\text { Infections (\%) }\end{array}$} & \multicolumn{2}{|c|}{$\begin{array}{l}\text { Mixed } \\
\text { Infections (\%) }\end{array}$} \\
\hline & & B. ovis & T. ovis & Theileria sp. & $\begin{array}{l}\text { Theileria } \\
\text { sp. OT3 }\end{array}$ & B. ovis & T. ovis & $\begin{array}{l}\text { Theileria } \\
\text { sp. }\end{array}$ & $\begin{array}{l}\text { Theileria } \\
\text { sp. OT3 }\end{array}$ & $\begin{array}{l}\text { B. ovis } \\
+ \\
\text { T. ovis }\end{array}$ & $\begin{array}{l}\text { T. ovis } \\
+ \\
\text { Theileria } \\
\text { sp. ОT3 }\end{array}$ \\
\hline January & 80 & $\begin{array}{l}0 \\
(0.00)\end{array}$ & $\begin{array}{l}6 \\
(7.50)\end{array}$ & $\begin{array}{l}8 \\
(10.00)\end{array}$ & $\begin{array}{l}9 \\
(11.25)\end{array}$ & $\begin{array}{l}0 \\
(0.00)\end{array}$ & $\begin{array}{l}6 \\
(7.50)\end{array}$ & $\begin{array}{l}8 \\
(10.00)\end{array}$ & $\begin{array}{l}9 \\
(11.25)\end{array}$ & $\begin{array}{l}0 \\
(0.00)\end{array}$ & $\begin{array}{l}0 \\
(0.00)\end{array}$ \\
\hline February & 80 & $\begin{array}{l}0 \\
(0.00)\end{array}$ & $\begin{array}{l}29 \\
(36.25)\end{array}$ & $\begin{array}{l}2 \\
(2.50)\end{array}$ & $\begin{array}{l}6 \\
(7.50)\end{array}$ & $\begin{array}{l}0 \\
(0.00)\end{array}$ & $\begin{array}{l}29 \\
(36.25)\end{array}$ & $\begin{array}{l}2 \\
(2.50)\end{array}$ & $\begin{array}{l}6 \\
(7.50)\end{array}$ & $\begin{array}{l}0 \\
(0.00)\end{array}$ & $\begin{array}{l}0 \\
(0.00)\end{array}$ \\
\hline March & 80 & $\begin{array}{l}0 \\
(0.00)\end{array}$ & $\begin{array}{l}40 \\
(50.00)\end{array}$ & $\begin{array}{l}8 \\
(10.00)\end{array}$ & $\begin{array}{l}6 \\
(7.50)\end{array}$ & $\begin{array}{l}0 \\
(0.00)\end{array}$ & $\begin{array}{l}36 \\
(45.00)\end{array}$ & $\begin{array}{l}8 \\
(10.00)\end{array}$ & $\begin{array}{l}2 \\
(2.50)\end{array}$ & $\begin{array}{l}0 \\
(0.00)\end{array}$ & $\begin{array}{l}4 \\
(5.00)\end{array}$ \\
\hline April & 80 & $\begin{array}{l}0 \\
(0.00)\end{array}$ & $\begin{array}{l}18 \\
(22.50)\end{array}$ & $\begin{array}{l}2 \\
(2.50)\end{array}$ & $\begin{array}{l}2 \\
(2.50)\end{array}$ & $\begin{array}{l}0 \\
(0.00)\end{array}$ & $\begin{array}{l}17 \\
(21.25)\end{array}$ & $\begin{array}{l}2 \\
(2.50)\end{array}$ & $\begin{array}{l}1 \\
(1.25)\end{array}$ & $\begin{array}{l}0 \\
(0.00)\end{array}$ & $\begin{array}{l}1 \\
(1.25)\end{array}$ \\
\hline May & 80 & $\begin{array}{l}0 \\
(0.00)\end{array}$ & $\begin{array}{l}47 \\
(58.75)\end{array}$ & $\begin{array}{l}4 \\
(5.00)\end{array}$ & $\begin{array}{l}7 \\
(8.75)\end{array}$ & $\begin{array}{l}0 \\
(0.00)\end{array}$ & $\begin{array}{l}45 \\
(56.25)\end{array}$ & $\begin{array}{l}4 \\
(5.00)\end{array}$ & $\begin{array}{l}5 \\
(6.25)\end{array}$ & $\begin{array}{l}0 \\
(0.00)\end{array}$ & $\begin{array}{l}2 \\
(2.50)\end{array}$ \\
\hline June & 80 & $\begin{array}{l}0 \\
(0.00)\end{array}$ & $\begin{array}{l}16 \\
(20.00) \\
\end{array}$ & $\begin{array}{l}10 \\
(12.50)\end{array}$ & $\begin{array}{l}1 \\
(1.25)\end{array}$ & $\begin{array}{l}0 \\
(0.00)\end{array}$ & $\begin{array}{l}16 \\
(20.00)\end{array}$ & $\begin{array}{l}10 \\
(12.50)\end{array}$ & $\begin{array}{l}1 \\
(1.25)\end{array}$ & $\begin{array}{l}0 \\
(0.00)\end{array}$ & $\begin{array}{l}0 \\
(0.00)\end{array}$ \\
\hline July & 80 & $\begin{array}{l}2 \\
(2.50)\end{array}$ & $\begin{array}{l}8 \\
(10.00)\end{array}$ & $\begin{array}{l}4 \\
(5.00)\end{array}$ & $\begin{array}{l}7 \\
(8.75)\end{array}$ & $\begin{array}{l}0 \\
(0.00)\end{array}$ & $\begin{array}{l}5 \\
(6.25)\end{array}$ & $\begin{array}{l}4 \\
(5.00)\end{array}$ & $\begin{array}{l}6 \\
(7.50)\end{array}$ & $\begin{array}{l}2 \\
(2.50)\end{array}$ & $\begin{array}{l}1 \\
(1.25)\end{array}$ \\
\hline August & 80 & $\begin{array}{l}1 \\
(1.25) \\
\end{array}$ & \begin{tabular}{|l}
6 \\
$(7.50)$ \\
\end{tabular} & $\begin{array}{l}14 \\
(17.50) \\
\end{array}$ & $\begin{array}{l}0 \\
(0.00) \\
\end{array}$ & $\begin{array}{l}1 \\
(1.25) \\
\end{array}$ & $\begin{array}{l}6 \\
(7.50) \\
\end{array}$ & \begin{tabular}{|l|}
14 \\
$(17.50)$ \\
\end{tabular} & $\begin{array}{l}0 \\
(0.00) \\
\end{array}$ & $\begin{array}{l}0 \\
(0.00)\end{array}$ & $\begin{array}{l}0 \\
(0.00)\end{array}$ \\
\hline September & 80 & $\begin{array}{l}0 \\
(0.00)\end{array}$ & $\begin{array}{l}8 \\
(10.00) \\
\end{array}$ & $\begin{array}{l}0 \\
(0.00) \\
\end{array}$ & $\begin{array}{l}0 \\
(0.00)\end{array}$ & $\begin{array}{l}0 \\
(0.00) \\
\end{array}$ & $\begin{array}{l}8 \\
(10.00)\end{array}$ & $\begin{array}{l}0 \\
(0.00) \\
\end{array}$ & $\begin{array}{l}0 \\
(0.00) \\
\end{array}$ & $\begin{array}{l}0 \\
(0.00) \\
\end{array}$ & $\begin{array}{l}0 \\
(0.00)\end{array}$ \\
\hline October & 80 & $\begin{array}{l}0 \\
(0.00)\end{array}$ & $\begin{array}{l}27 \\
(33.75)\end{array}$ & $\begin{array}{l}1 \\
(1.25)\end{array}$ & $\begin{array}{l}1 \\
(1.25)\end{array}$ & $\begin{array}{l}0 \\
(0.00)\end{array}$ & $\begin{array}{l}27 \\
(33.75)\end{array}$ & $\begin{array}{l}1 \\
(1.25)\end{array}$ & $\begin{array}{l}1 \\
(1.25)\end{array}$ & $\begin{array}{l}0 \\
(0.00)\end{array}$ & $\begin{array}{l}0 \\
(0.00)\end{array}$ \\
\hline November & 80 & $\begin{array}{l}0 \\
(0.00)\end{array}$ & $\begin{array}{l}16 \\
(20.00)\end{array}$ & $\begin{array}{l}0 \\
(0.00)\end{array}$ & $\begin{array}{l}0 \\
(0.00)\end{array}$ & $\begin{array}{l}0 \\
(0.00)\end{array}$ & $\begin{array}{l}16 \\
(20.00)\end{array}$ & $\begin{array}{l}0 \\
(0.00)\end{array}$ & $\begin{array}{l}0 \\
(0.00)\end{array}$ & $\begin{array}{l}0 \\
(0.00)\end{array}$ & $\begin{array}{l}0 \\
(0.00)\end{array}$ \\
\hline December & 80 & $\begin{array}{l}0 \\
(0.00)\end{array}$ & $\begin{array}{l}17 \\
(21.25) \\
\end{array}$ & $\begin{array}{l}6 \\
(7.50) \\
\end{array}$ & $\begin{array}{l}2 \\
(2.50) \\
\end{array}$ & $\begin{array}{l}0 \\
(0.00)\end{array}$ & $\begin{array}{l}16 \\
(20.00)\end{array}$ & \begin{tabular}{|l}
6 \\
$(7.50)$ \\
\end{tabular} & $\begin{array}{l}1 \\
(1.25) \\
\end{array}$ & $\begin{array}{l}0 \\
(0.00) \\
\end{array}$ & $\begin{array}{l}1 \\
(1.25) \\
\end{array}$ \\
\hline $\begin{array}{l}\text { Total } \\
(\%)\end{array}$ & 960 & $\begin{array}{l}3 \\
(0.31)\end{array}$ & \begin{tabular}{|l|}
238 \\
$(24.79)$ \\
\end{tabular} & $\begin{array}{l}59 \\
(6.15) \\
\end{array}$ & $\begin{array}{l}41 \\
(4.27) \\
\end{array}$ & $\begin{array}{l}1 \\
(0.10)\end{array}$ & $\begin{array}{l}227 \\
(23.65)\end{array}$ & \begin{tabular}{|l|}
59 \\
$(6.15)$ \\
\end{tabular} & $\begin{array}{l}32 \\
(3.33) \\
\end{array}$ & $\begin{array}{l}2 \\
(0.21) \\
\end{array}$ & $\begin{array}{l}9 \\
(0.94) \\
\end{array}$ \\
\hline \multicolumn{2}{|l|}{$\mathbf{p}^{*}$} & 0.107 & 0.000 & 0.000 & 0.000 & 0.443 & 0.000 & 0.000 & 0.000 & 0.024 & 0.026 \\
\hline
\end{tabular}

species that is mostly reported in forest areas in cold and highaltitude northern regions and is seen on sea coasts up to 8001.000 meters altitude. Therefore, it is more common in Kars compared to the mentioned provinces (27). The altitude of the Kars Region is as high as 1.800 meters and the higher rate of $D$. marginatus species detected is in line with the literature. Also, in a study conducted on tick infestations in cattle in the Kars Region (28), D. marginatus species was found to be widespread, indicating that the prevalence of $D$. marginatus was higher in both cattle and sheep in this region. Tick species in the Haemaphysalis genus are found in Turkey where vegetation is rich, with large forest areas, a soft continental climate, and a high altitude (29). Our findings are in line with other studies. Rhipicephalus bursa was seen in places with a Mediterranean climate, covered with maquis vegetation, not too hot in summer, short and moderate winters, and rugged terrain (30). In the present study, $R$. bursa (0.53\%) and $H$. marginatum $(0.11 \%)$ in sheep in the Kars Region were found to be less prevalent than those reported in other studies.
According to the collection foci/settlement, the highest rate of D. marginatus was 25.63\% (242/944) in Kars City Center, whereas this species was not found in Kagizman. This can be explained by the fact that the center of Kars includes a high plateau and altitude. It was thought that the lower rate in Kagizman may be due to the lower altitude and location in the valley. It has been reported that the highest rate of Hae. parva in Digor (15.36\%), Hae. punctata in Sarıkamıs (1.67\%) R. bursa in Kagizman (44.44\%) and H. marginatum in Akyaka (0.43\%). These results support that the distribution of tick species may differ according to foci/settlement which is related to the distribution of vector ticks.

In the present study, the presence of Babesia and Theileria species in ticks collected from sheep was also investigated. In this study, as in other studies $(5,6,31)$, no pathogenic species were found in the analysis of egg clusters or tick carcasses with the RLB method. This is due to the fact that there are no pathogenic species in the detected tick species. 
Table 5. Distribution of tick infestation in sheep by months

\begin{tabular}{|l|l|l|l|l|l|l|}
\hline Months & NSE & NSI & IR (\%) & NTC & ID & ANT \\
\hline January & 80 & 1 & 1.25 & 1 & 1 & 0.01 \\
\hline February & 80 & 1 & 1.25 & 1 & 1 & 0.01 \\
\hline March & 80 & 0 & 0.0 & 0 & 0 & 0 \\
\hline April & 80 & 26 & 32.5 & 239 & 9.2 & 0.33 \\
\hline May & 80 & 13 & 16.25 & 55 & 4.23 & 0.16 \\
\hline June & 80 & 4 & 5.0 & 4 & 1.25 & 0.05 \\
\hline July & 80 & 0 & 0.0 & 0 & 0 & 0 \\
\hline August & 80 & 21 & 26.25 & 55 & 2.62 & 0.26 \\
\hline September & 80 & 11 & 13.75 & 71 & 6.45 & 0.14 \\
\hline October & 80 & 36 & 45.0 & 199 & 5.53 & 0.45 \\
\hline November & 80 & 35 & 43.75 & 225 & 6.43 & 0.44 \\
\hline December & 80 & 20 & 25.0 & 94 & 4.7 & 0.25 \\
\hline Total & $\mathbf{9 6 0}$ & $\mathbf{1 6 8}$ & $\mathbf{1 7 . 5}$ & $\mathbf{9 4 4}$ & $\mathbf{5 . 6 2}$ & $\mathbf{0 . 9 8}$ \\
\hline
\end{tabular}

NSE: The number of sheep examined, NSI: The number of infested sheep, IR: Infestation rate, NTC: The number of ticks collected, ID: Infestation density, ANT: The average number of ticks

\section{CONCLUSION}

This study covers the entire Kars Region. The research was carried out on randomly selected sheep that did not show clinical signs, so $B$. ovis, which is a pathogenic species for sheep, and $R$. bursa species tick, which carries this infection, was found at a very low rate. It had been determined that $T$. ovis was the responsible species for theileriosis agent in sheep in the region. Species commonly detected in tick-infested sheep were D. marginatus and Hae. parva. The data obtained from the present study will help in determining the species and ecological characteristics of the ticks in the region, as well as in creating risk maps of these tick-borne diseases in the future, and determining prevention and control strategies. Additional studies are needed to detect the pathogens in vector ticks.

\section{*ACKNOWLEDGES}

This study was summarized from the first name author's doctoral thesis and was supported by the Scientific Research Projects Coordination Office of Kafkas University (project no: 2017-TS-35). This study was presented one part as oral presentation (seasonal distribution of tick species of the Kars region in Turkey) on July 24-26, 2018 at the Fifth International Multidisciplinary Congress of Eurasia (IMCOFE), Barcelona/Spain. Another part of it (Molecular epidemiology of Babesia and Theileria species in sheep in the Kars region) on 28 September-3 October, 2019, at the Twenty-first Parasitology Congress, Cesme/Izmir/ Turkey.

\section{*Ethics}

Ethics Committee Approval: For this study, Kafkas University Animal Experiments from the Local Ethics Committee (letter dated: 15.12.2016 and numbered: 2016-131) approval has been received.

Informed Consent: In the study, with the permission of the animal owners, samples were collected and used in the study.

Peer-review: Externally and internally peer-reviewed.

\section{*Authorship Contributions}

Concept: N.A., Z.V., M.Ö.A., Design: N.A., Z.V., M.Ö.A., Data Collection or Processing: N.A., Z.V., M.Ö.A., Analysis or Interpretation: N.A., Z.V., M.Ö.A., Literature Search: N.A., Z.V., M.Ö.A., Writing:. N.A., Z.V., M.Ö.A.

Conflict of Interest: The authors have declared no conflict of interest statement.

Financial Disclosure: This study was supported by the Scientific Research Projects Coordination Office of Kafkas University (project no: 2017-TS-35).

\section{REFERENCES}

1. Karatepe B, Ozubek S, Karatepe M, Aktas M. Detection of Theileria and Babesia species in sheep and goats by microscopy and molecular methods in Nigde province, Turkey. Revue Med Vet 2019; 170: 136-43.

2. Aydın MF, Aktas M, Dumanli N. Molecular identification of Theileria and Babesia in sheep and goats in the Black Sea Region in Turkey. Parasitol Res 2013; 112: 2817-24.

3. Aktas M, Ozubek S. A survey of canine haemoprotozoan parasites from Turkey, including molecular evidence of an unnamed Babesia. Comp Immunol Microbiol Infect Dis 2017; 52: 36-42.

4. Nagore D, García-Sanmartín J, García-Pérez AL, Juste RA, Hurtado A. Identification, genetic diversity and prevalence of Theileria and Babesia species in a sheep population from Northern Spain. Int J Parasitol 2004; 34: 1059-67.

5. Altay K, Atas AD, Ozkan E. Molecular survey of Theileria and Babesia species in small ruminants and ticks from Sivas region of Turkey. Manas J Agr Vet Life Sci 2017; 7: 30-9.

6. Bilgic HB, Bakırcı S, Kose O, Unlu AH, Hacılarloglu S, Eren $\mathrm{H}$, et al. Prevalence of tick-borne haemoparasites in small ruminants in Turkey and diagnostic sensitivity of single-PCR and RLB. Parasit Vectors 2017; 10: 211 .

7. Uilenberg G, Gray J, Kahl O. Research on Piroplasmorida and other tickborne agents: Are we going the right way? Ticks Tick Borne Dis. 2018; 9: 860-3.

8. Ozubek S. Adana, Mersin, Gaziantep ve Adıyaman illerinde koyun ve keçilerde Theileria ve Babesia türlerinin araştırılması. PhD Dissertation. Firat Univ. 2016.

9. Estrada-Pena A, Bouattour A, Camicas JL, Walker AR, editors. Ticks of Domestic Animals in the Mediterranean Region: A Guide to Identification of Species. 1sted. Publised by University of Zaragoza, Spain: 2004. p. 1-128.

10. Georges K, Loria GR, Riili S, Greco A, Caracappa S, Jongejan F, et al. Detection of haemoparasites in cattle by reverse line blot hybridisation with a note on the distribution of ticks in Sicily. Vet Parasitol 2001; 99: 273-86.

11. Gubbels JM, de Vos AP, van der Weide M, Viseras J, Schouls LM, de Vries E, et al. Simultaneous detection of bovine Theileria and Babesia species by reverse line blot hybridization. J Clin Microbiol 1999; 37: 1782-9.

12. Schnittger L, Yin H, Qi B, Gubbels MJ, Beyer D, Niemann S, et al. Simultaneous detection and differentiation of Theileria and Babesia parasites infecting small ruminants by reverse line blotting. Parasitol Res 2004; 92: 189-96

13. Altay K, Aktas M, Dumanli N, Aydın MF. Evaluation of a PCR and comparison with RLB for detection and differentiation of Theileria sp. MK and other Theileria and Babesia species of small ruminants. Parasitol Res 2008; 103: 319-23

14. Adamu M, Troskie M, Oshadu DO, Malatji DP, Penzhorn BL, Matjila PT. Occurrence of tick-transmitted pathogens in dogs in Jos, Plateau State, Nigeria. Parasit Vectors 2014; 7: 119 .

15. Oosthuizen MC, Zweygarth E, Collins NE, Troskie M, Penzhorn BL. Identification of a novel Babesia sp. from a sable antelope (Hippotragus niger Harris, 1838). J Clin Microbiol 2008; 46: 2247-51. 
16. Can A.SSPS ile bilimsel araştırma sürecinde nicel veri analizi. 5th ed, Pegem Akademi Publishing; Ankara, Turkey. 2017.

17. Aktas M, Dumanlı N, Altay K. Elazığ yöresinde koyun ve keçilerde Theileria ovis'in polimeraz zincir reaksiyonu ile araştırılması [Survey of Theileria ovis in sheep and goats in the Elazig region using the polymerase chain reaction.]. Turkiye Parazitol Derg 2005; 29: 17-21.

18. Renneker S, Abdo J, Bakheit MA, Kullmann B, Beyer D, Ahmed J, Coet al. infection of sheep with Anaplasma, Theileria and Babesia species in the Kurdistan Region, Iraq. Transbound Emerg Dis. 2013; 60 (Suppl 2): 113-8.

19. Lee SH, Mossaad E, Ibrahim AM, Ismail AA, Adjou Moumouni PF, Liu M, et al. Detection and molecular characterization of tick-borne pathogens infecting sheep and goats in Blue Nile and West Kordofan states in Sudan. Ticks Tick Borne Dis 2018; 9: 598-604.

20. Altay K, Aydın MF, Uluısık U, Aktaş M, Dumanlı N. Theileria annulata ve Theileria buffeli'nin Teşhisinde Multiplex PCR'in Kullanılmasi [Use of multiplex PCR for the diagnosis of Theileria annulata and Theileria buffeli]. Turkiye Parazitol Derg 2008; 32: 1-3.

21. Khukhuu A, Lan DT, Long PT, Ueno A, Li Y, Luo Y, et al. Molecular epidemiological survey of Theileria orientalis in Thua Thien Hue Province, Vietnam. J Vet Med Sci 2011; 73: 701-5.

22. Sayın F, Dinçer S, Karaer Z, Dumanlı N, Cakmak A, Inci A, et al. Status of tick infestation of sheep and goats in Turkey. Parassitologia 1997; 39: 145-52.
23. Akdemir C. Van ve yöresi koyunlarında bulunan kene türlerinin (Fam: Ixodidae) tespiti ve epidemiyolojisi üzerine araştırmalar. PhD Dissertation, Van Yüzüncü Yll Üniversitesi. 2001.

24. Sayın F, Nalbantoglu S, Yukarı BA, Cakmak A, Karaer Z. Epidemiological studies on sheep and goat Theileria infection. Ankara Üniv Vet Fak Derg 2009; 56: 127-9.

25. Aydın L, Bakırcı S. Geographical distribution of ticks in Turkey. Parasitol Res 2007; 101 (Suppl 2): S163-6.

26. Aydın MF. Karadeniz Bölgesinde koyun ve keçilerde Theileria ve Babesia türlerinin moleküler yöntemlerle belirlenmesi. PhD Dissertation. Firat Universitesi. 2011.

27. Estrada-Peña A, Santos-Silva MM. The distribution of ticks (Acari: Ixodidae) of domestic livestock in Portugal. Exp Appl Acarol 2005; 36: 233-46.

28. Arslan MO, Umur S, Aydın L. The prevalence of Ixodidae species on cattle in Kars province of Turkey. Turkiye Parazitol Derg 1999; 23: 331-5.

29. Cicek H. Ankara yöresinde Haemaphysalis türleri üzerinde epizootolojik araştırmalar. Turk J Vet Anim Sci 2004; 28: 107-13.

30. Torina A, Khoury C, Caracappa S, Maroli M. Ticks infesting livestock on farms in Western Sicily, Italy. Exp Appl Acarol 2006; 38: 75-86.

31. Chaligiannis I, Fernández de Mera IG, Papa A, Sotiraki S, de la Fuente J. Molecular identification of tick-borne pathogens in ticks collected from dogs and small ruminants from Greece. Exp Appl Acarol 2018; 74: 44353 . 